\title{
Does CD4+CD25+foxp3+ cell (Treg) and IL-I 0 profile determine susceptibility to immune reconstitution inflammatory syndrome (IRIS) in HIV disease?
}

\author{
Esaki Muthu Shankar, Ramachandran Vignesh, Vijayakumar Velu, \\ Kailapuri G Murugavel, Ramalingam Sekar, Pachamuthu Balakrishnan, \\ Charmaine AC Lloyd, Shanmugam Saravanan, Suniti Solomon and \\ Nagalingeswaran Kumarasamy*
}

Address: YRG Centre for AIDS Research and Education, VHS Hospital Campus, Rajiv Gandhi Salai-Information Technology Corridor, Taramani, Chennai 600 113, India

Email: Esaki Muthu Shankar - shankarem@yrgcare.org; Ramachandran Vignesh - vignesh@yrgcare.org;

Vijayakumar Velu - vvjai2000@yahoo.com; Kailapuri G Murugavel - murugavel@yrgcare.org; Ramalingam Sekar - sekar@yrgcare.org;

Pachamuthu Balakrishnan - bala@yrgcare.org; Charmaine AC Lloyd - charmaine@yrgcare.org; Shanmugam Saravanan - saravanan@yrgcare.org; Suniti Solomon - suniti@yrgcare.org; Nagalingeswaran Kumarasamy* - kumarasamy@yrgcare.org

* Corresponding author

Published: 18 February 2008

Journal of Inflammation 2008, 5:2 doi:10.1 186/1476-9255-5-2
Received: 26 November 2007

Accepted: 18 February 2008

This article is available from: http://www.journal-inflammation.com/content/5/I/2

(C) 2008 Shankar et al; licensee BioMed Central Ltd.

This is an Open Access article distributed under the terms of the Creative Commons Attribution License (http://creativecommons.org/licenses/by/2.0), which permits unrestricted use, distribution, and reproduction in any medium, provided the original work is properly cited.

\begin{abstract}
HIV-specific T-lymphocyte responses that underlie IRIS are incomplete and largely remain hypothetical. Of the several mechanisms presented by the host to control host immunological damage, Treg cells are believed to play a critical role. Using the available experimental evidence, it is proposed that enormous synthesis of conventional FoxP3. Th cells (responsive) often renders subjects inherently vulnerable to IRIS, whereas that of natural FoxP3+ Treg cell synthesis predominate among subjects that may not progress to IRIS. We also propose that IRIS nondevelopers generate precursor $T$-cells with a high avidity to generate $C D 4+C D 25+F o x P 3+$ Tregs whereas IRIS developers generate T-cells of intermediate avidity yielding Th0 cells and effector Tcells to mediate the generation of proinflammatory cytokines in response to cell-signaling factors (IL-2, IL-6 etc.). Researchers have shown that IL-10 Tregs (along with TGF- $\beta$, a known antiinflammatory cytokine) limit immune responses against microbial antigens in addition to effectively controlling HIV replication, the prime objective of HAART. Although certain technical limitations are described herein, we advocate measures to test the role of Tregs in IRIS.
\end{abstract}

The hide and seek game in immune reconstitution inflammatory syndrome (IRIS): The factor?

The immune reconstitution inflammatory syndrome (IRIS) in HIV-infected patients initiating highly active antiretroviral therapy (HAART) leading to 'paradoxical clinical worsening' [1] results from restored immunity to specific infectious or non-infectious antigens [2-10]. Possible mechanisms include a partial recovery of the host immune system or exuberant immunological responses to antigenic stimuli. The overall frequency of IRIS is undefined, but is believed to be dependent on underlying 
opportunistic infectious (mycobacteria, varicella zoster, herpesviruses, and cytomegalovirus) and non-infectious (autoimmune) burdens [2-10]. Of the subjects that are initiated on HAART, only a proportion progress to develop IRIS and the remaining never develop IRIS despite an exuberant immune restoration from poor baseline CD4+ T-cell levels. Recently, we proposed that subjects that develop IRIS generate a high burden of proinflammatory cytokines in response to enormous levels of systemic bacterial LPS as compared with less LPS in IRIS non-developers [11]. Although several other mechanisms have been proposed, HIV-specific T-cell responses underlying IRIS are incomplete [12]. To investigate the inflammatory intermediaries of IRIS it will be crucial to explain the intrinsic dynamics of immune cells after initiating HAART [13]. Furthermore, factors that confers resistance to development of IRIS among IRIS non-developers needs to be described.

\section{Possible role of memory T-cells in IRIS}

The majority of individuals with HIV infection in resource-constrained settings attend HIV testing centres only after progression to terminal stage of HIV disease (i.e. when their CD4+ T-cell counts are very low) [1,14]. Therefore, these subjects with the most severe immunosuppression (CD4+ T-cell nadirs, 100 cells $/ \mu \mathrm{L})$, initiating antiretroviral regimens may be at the highest risk for the development of IRIS [15]. Conceptually, any individual harboring microbial antigens should mount an over-exuberant immune response against any pre-existing antigen (e.g. mycobacterial, cryptococcal, strongyloidal, etc.), which at times may be detrimental to the host owing to subsequent inflammatory reactions that follow the restoration.

Reconstitution of memory cell responses is the initial hallmark of restoration of pathogen specific immune responses after initiation of HAART. Recent evidence suggests that the immune restoration following HAART is characterized by enormous memory CD4+ T-cell types $(\mathrm{CD} 4+\mathrm{CD} 45 \mathrm{RO}+)$ likely due to peripheral lymphoid redistribution $[16,17]$. A characteristic 2-phase increase in CD4 T-cells occurs after initiating HAART; a rapid initial increase in memory $\mathrm{T}$ cells in the first few months, followed by a steady rise in naive T-cells that continue for years with sustained therapy. Furthermore, recovery of lost responses occurring during the early phase could also be attributed to cellular redistribution rather than a de novo specific CD4+ T-cell proliferation since naive activated CD4+ T-cells (CD4+CD45RA+CD62L+) do not recover until after several months of therapy. The feature and strength of this response may account the early-onset of IRIS [3]. Moreover, an increase in the concentrations of IFN- $\gamma$ and IL-2 are reportedly responsible for this phenomenon. There are a few studies to support the prolifer- ation of peripheral blood mononuclear cells, antigen specific CD4+ T-cells and IFN- $\gamma$ response to Mycobacterium tuberculosis antigens after initiation of HAART in HIVinfected patients $[18,19]$. The activated CD4+ T-cells are subsequently primed to recognize previous antigenic stimuli, and might account for the subsequent manifestations of IRIS. This, possibly could be due to the fact that generation of post-HAART immune components always arise from residual immune cells that had undergone extensive immune activation rather than the newly synthesized cells. Researchers have also shown that improvement in antigen-specific $\mathrm{T}$-cell restoration could be attributed to an increase in memory CD4+ T-cell number but not with increase in CD4+ T-cell number or decrease in plasma viral load (PVL) [20]. Further, the study has shown that improvement in delayed type hypersensitivity (DTH) response was significantly associated only with a decline in PVL [20].

\section{IRIS developers vs IRIS non-developers: Are Tregs the determinants of inflammation after initiating HAART?}

Of the several mechanisms put forth by the host to regulate immunological damage caused by over-exuberant immune responses, Treg cells are believed to play a critical role in regulating inflammatory responses by mediating key components that facilitate immune suppression [2125]. Of the various Treg populations described, the CD $4{ }^{+} \mathrm{CD} 25^{+}$and $\mathrm{CD} 4{ }^{+} \mathrm{CD} 45 \mathrm{RB}^{\text {low }}$ cells function via the action of IL-10 [26], cytotoxic T-cell-associated protein 4 (CTLA4) $[27,28]$, and/or TGF- $\beta$ [26-33], while other Tregs secrete IL-10 [31-40] and TGF- $\beta$ [41]. Tregs and naïve helper T cells (Th0) are proposed to develop within a normal thymus through positive and negative selection processes. On the one hand, it is proposed that enormous generation of conventional FoxP3. Th cells (CD5 low, CD11a low $^{\text {lon }}$ CD25 low, CD 38 low,$C D 44^{\text {low }}$ CD45RB high, CD54 ${ }^{\text {low }}$, CD $103 \varepsilon^{\text {low }}$ GITR ${ }^{\text {low }}$ ), that reportedly are panergic to T-cell stimuli and non-suppressive, predominate among subjects that are inherently vulnerable to IRIS. On the other hand, the high turnover of natural FoxP3+ Treg cells (CD5high, CD11 a $^{\text {high }}, \mathrm{CD} 25^{\text {high }}, \mathrm{CD} 38^{\text {high }}, \mathrm{CD} 44^{\text {high }}$, CD45RB ${ }^{\text {low }}$ CD54high, CD103 ${ }^{\text {high }}$, GITR ${ }^{\text {high }}$ ), that are conventionally non-responsive to T-cell stimuli and suppressive (normally beneficial, as it may help limit the severity of tissue destruction associated with an inflammatory condition due to infection), predominate among subjects that may not progress to IRIS. Therefore, precursor T-cells of relatively high avidity trigger Treg development via the activation of Foxp3 (forkhead/winged-helix family transcriptional repressor), whereas T-cell receptors of intermediate avidity yield conventional Th0 cells. We propose that IRIS non-developers generate precursor T-cells with a high avidity to generate CD4+CD25+FoxP3+ Tregs whereas IRIS developers generate T-cells of intermediate 
avidity yielding Th0 cells and effector T-cells to mediate the generation of proinflammatory cytokines in response to cell-signaling factors (IL-2, IL-6 etc.). We propose that IRIS non-developers possess Foxp $3^{+}$in the naturally occurring Tregs that inhibit CD4+ ${ }^{+}$-cell proliferation through IL-10-independent, cell contact-dependent mechanisms. This mechanism has already been demonstrated in certain other inflammatory conditions. Besides this, plasmacytoid dendritic cells (pDC) expressing ICOS ligand (ICOS-L) appears to be responsible for the generation of IL-10 Tregs. Tregs are known to suppress cellular proliferation and cytokine production by $\mathrm{CD} 4^{+}$and $\mathrm{CD} 8^{+}$ T-cells in response to microbial antigens. Researchers have shown that IL-10 levels are raised after HAART among IRIS developers $[13,42]$. Furthermore, IL-10 Tregs also limit immune responses against microbial antigens $(M$. tuberculosis) in addition to controlling HIV replication $[42,43]$. Tregs also suppress HIV-induced proliferation of perforin-expressing CD8 ${ }^{+} \mathrm{T}$-cells, which otherwise, could mediate inflammation $[42,44,45]$. Both Th1 and Th2 responses can be controlled by IL-10 Tregs and by naturally occurring Tregs [46]. It is to be remembered that Th1 cells producing IFN- $\gamma$ are critical for obliterating intracellular pathogens, notably M. tuberculosis and Listeria monocytogenes, but are also implicated in inflammatory pathologies $[47,48]$. Th2 cells, on the other hand, which produce IL-4, IL-5, and IL-13, are important for the regulation of immune responses to helminths but also cause allergic pathologies $[47,49]$. IL-4 and IL-13 are implicated in inhibiting the generation of proinflammatory cytokines by macrophages [49]. In addition to being regulated by naturally occurring Tregs and by IL-10 Tregs, Th1 and Th2 cells also reciprocally regulate the development and function of each other. Because IL-10 is also produced by B lymphocytes, macrophages, DCs and T cells other than Tregs, it is clear that multiple cell types could contribute to the regulation of host immune responses via their production of IL-10. IL-10 is reported to be essential in limiting immune responses to inflammation $[42,50]$. Research on experimental animals has shown that the deletion of IL-10 gene could facilitate susceptibility to inflammatory bowel disease and colitis $[49,50]$. Thus regulation of the immune response may occur at various levels, each utilizing different mechanisms that, depending on the degree of inflammation and the host response to infection, are called upon at different stages during immune responses. The regulatory capacity of antigen-driven IL-10 Tregs and of naturally occurring Tregs and the induction of immunosuppressive cytokines (IL-10 and TGF- $\beta$ ) provide a new level of immune regulation to inhibit both Th1- and Th2-type immune responses [50]. Treg fitness could be another possible approach that appears to be of interest with regard to Treg levels in chronic HIV disease. Although, we propose to test the immunosuppressive role of Tregs in IRIS, we do foresee certain limitations for testing the hypotheses. While CD4/ CD25/FoxP3 are well-cited markers for Tregs, there appears to be a consensus in the flow cytometry community on which markers actually define the Treg population (activated and non-activated) in the presence of HIV infection. Furthermore, Tregs are often reported to be few in numbers in flow cytometric analyses and therefore in the setting of HIV infection, it is questionable as to whether the frequency of these cells is sufficient for testing the proposed hypothesis. Future attempts using sophisticated tools and technologies might render this possible. We also warrant future research required to reveal the mechanisms that underlie the possible role of APCs, effector molecules, such as IL-10 and TGF- $\beta$, secreted by Tregs in determining the susceptibility of individuals to IRIS.

\section{Conclusion}

We propose to test whether IRIS non-developers generate precursor T-cells with a high avidity to generate CD4+CD25+FoxP3+ Tregs and whether IRIS developers generate T-cells of intermediate avidity yielding Th0 cells and effector T-cells. Although researchers have shown that IL-10 Tregs control immune responses against foreign antigens in addition to effectively controlling HIV replication, the prime objective of HAART, this needs to be intensively investigated. Attempts have never been thrown to reveal the role of tregs in IRIS and FoxP3 gene till date. The hypothesis can be either tested in a disease-specific approach (i.e. examining the role of Tregs in TB-IRIS subjects) or by examining all forms of IRIS (both infectious and non-infectious). In addition, the role of polymorphisms in TNF- $\alpha$ and IL- 6 promotors can also be examined as these too could play a significant role in mediating IRIS.

\section{Competing interests}

The author(s) declare that they have no competing interests.

\section{Authors' contributions}

EMS, RV, VV and NK conceived and proposed the hypothesis. RV, KGM, RS, PB, CACL, SSo, and NK provided additional inputs to further develop the scientific concept; EMS, RV, SSa, RS and PB drafted the manuscript; SSo and NK shared their clinical expertise and critically revised the manuscript. All authors read and approved the final manuscript. EMS, RV and NK are the guarantors of the paper.

\section{Acknowledgements}

The authors are grateful to all the staff and patients of YRG CARE without whose support and facilitation, this manuscript could not have been conceived and drafted.

\section{References}

I. Kumarasamy N, Chaguturu S, Mayer KH, Solomon S, Yepthomi HT, Balakrishnan $P$, et al.: Incidence of immune reconstitution syn- 
drome in HIV/tuberculosis-coinfected patients after initiation of generic antiretroviral therapy in India. J Acquir Immune Defic Syndr 2004, 37:1574-I576.

2. Keane NM, Price P, Lee S, Almeida CA, Stone SF, James I, French MA: Restoration of CD4 $\mathrm{T}$-cell responses to cytomegalovirus is short-lived in severely immunodeficient HIV-infected patients responding to highly active antiretroviral therapy. HIV Med 2004, 5:407-4I4.

3. Stone SF, Price P, Brochier J, French MA: Plasma bioavailable interleukin-6 is elevated in human immunodeficiency virusinfected patients who experience herpes virus-associated immune restoration disease after start of highly active antiretroviral therapy. J Infect Dis 200I, I 84:I073-I077.

4. Koval CE, Gigliotti F, Nevins D, Demeter LM: Immune reconstitution syndrome after successful treatment of Pneumocystis carinii pneumonia in a man with human immunodeficiency virus type I infection. Clin Infect Dis 2002, 35:49|-493.

5. Bicanic T, Harrison T, Niepieklo A, Dyakopu N, Meintjes G: Symptomatic relapse of HIV-associated cryptococcal meningitis after initial fluconazole monotherapy: the role of fluconazole resistance and immune reconstitution. Clin Infect Dis 2006, 43:1069-1073.

6. Lawn SD, Bicanic TA, Macallan DC: Pyomyositis and cutaneous abscesses due to Mycobacterium avium : an immune reconstitution manifestation in a patient with AIDS. Clin Infect Dis 2004, 38:46I-463.

7. Sereti I, Sarlis NJ, Arioglu E, Turner ML, Mican JM: Alopecia universalis and Graves' disease in the setting of immune restoration after highly active antiretroviral therapy. AIDS 200I, I 5: I38-140.

8. Mirmirani P, Maurer TA, Herndier B, McGrath M, Weinstein MD, Berger TG: Sarcoidosis in a patient with AIDS: a manifestation of immune restoration syndrome. J Am Acad Dermatol 1999, $41: 285-286$

9. Lawn SD, Checkley A, Wansbrough-Jones $\mathrm{MH}$ : Acute bilateral parotitis caused by Mycobacterium scrofulaceum : immune reconstitution disease in a patient with AIDS. Sex Transm Infect 2005, $81: 517-518$.

10. Taylor CL, Subbarao V, Gayed S, Ustianowski AP: Immune reconstitution syndrome to Strongyloides stercoralis infection. AIDS 2007, 2 I:649-650.

II. Shankar EM, Vignesh R, Murugavel KG, Balakrishnan P, Lloyd CA, Sekar R, Solomon S, Kumarasamy N: Immune reconstitution inflammatory syndrome in association with HIVIAIDS and tuberculosis: Views over hidden possibilities. AIDS Res Ther 2007, 4:29.

12. Shelburne SA, Montes M, Hamill RJ: Immune reconstitution inflammatory syndrome: more answers, more questions. J Antimicrob Chemother 2006, 57:167-170.

13. Bourgarit A, Carcelain G, Martinez V, Lascoux C, Delcey V, Gicquel B, Vicaut E, Lagrange PH, Sereni D, Autran B: Explosion of tuberculin-specific ThI-responses induces immune restoration syndrome in tuberculosis and HIV co-infected patients. AIDS 2006, 20:FI-F7.

14. Kumarasamy N, Vallabhaneni S, Flanigan TP, Mayer KH, Solomon S: Clinical profile of HIV in India. Indian J Med Res 2005, | 2 | :377-394.

15. Shelburne S, Visnegarwala F, Darcourt J, Graviss E, Giordano T, White AC Jr, Hamill RJ: Incidence and risk factors for immune reconstitution inflammatory syndrome during highly active antiretroviral therapy. AIDS 2005, 19:399-406.

16. Bucy RP, Hockett RD, Derdeyn CA, Saag MS, Squires K, Sillers M, Mitsuyasu RT, Kilby JM: Initial increase in blood CD4(+) lymphocytes after HIV antiretroviral therapy reflects redistribution from lymphoid tissues. J Clin Invest 1999, I03:|39|-1398.

17. Autran B, Carcelain G, Li TS, Blanc C, Mathez D, Tubiana R, Katlama $C$, Debré $P$, Leibowitch J: Positive effects of combined antiretroviral therapy on CD4+ $T$ cell homeostasis and function in advanced HIV disease. Science 1997, 277: I I2-I I6.

18. Narendran G, Swaminathan S, Sathish S, Rajasekaran S: Immune reconstitution syndrome in a child with TB and HIV. Indian J Pediatr 2006, 73:627-629.

19. Swaminathan S, Padmapriya C, Narendran G, Thomas B, Anand S, Rajalakshmi A: Immune reconstitution syndrome following ini- tiation of antiretroviral therapy in HIV and multidrug resistant tuberculosis. Indian J Chest Dis Allied Sci 2005, 47:299-304.

20. Wendland T, Furrer H, Vernazza PL, Frutig K, Christen A, Matter L, MPichler WJ: HAART in HIV-infected patients: restoration of antigen-specific CD4 $\mathrm{T}$-cell responses in vitro is correlated with CD4 memory T-cell reconstitution, whereas improvement in delayed type hypersensitivity is related to a decrease in viraemia. AIDS 1999, I3:1857-1862.

21. Sakaguchi S, Sakaguchi N, Asano M, Itoh M, Toda M: Immunologic self-tolerance maintained by activated $T$ cells expressing IL2 receptor alpha-chains (CD25). Breakdown of a single mechanism of self-tolerance causes various autoimmune diseases. J Immunol 1995, I 55: I I 5 I-I I 64.

22. Sakaguchi S, Sakaguchi N, Shimizu J, Yamazaki S, Sakihama T, Itoh M, Kuniyasu Y, Nomura T, Toda M, Takahashi T: Immunologic tolerance maintained by CD25+ CD4+ regulatory $T$ cells: their common role in controlling autoimmunity, tumor immunity, and transplantation tolerance. Immunol Rev 200I, I 82: 18-32.

23. Shevach EM: Suppressor T cells: Rebirth, function and homeostasis. Curr Biol 2000, I0:R572-R575.

24. Powrie F, Correa-Oliveira R, Mauze S, Coffman RL: Regulatory interactions between CD45RB high and CD45RBlow CD4+ T cells are important for the balance between protective and pathogenic cell-mediated immunity. J Exp Med 1994, I 79:589-600.

25. Maloy KJ, Powrie F: Regulatory T cells in the control of immune pathology. Nat Immunol 200I, 2:816-822.

26. Asseman C, Mauze S, Leach MW, Coffman RL, Powrie F: An essential role for interleukin 10 in the function of regulatory $T$ cells that inhibit intestinal inflammation. J Exp Med 1999, 190:995-1004.

27. Read S, Malmstrom V, Powrie F: Cytotoxic T lymphocyte-associated antigen 4 plays an essential role in the function of CD25(+)CD4(+) regulatory cells that control intestinal inflammation. J Exp Med 2000, 1 92:295-302.

28. Takahashi T, Tagami T, Yamazaki S, Uede T, Shimizu J, Sakaguchi N, Mak TW, Sakaguchi S: Immunologic self-tolerance maintained by CD25(+)CD4(+) regulatory $T$ cells constitutively expressing cytotoxic $\mathbf{T}$ lymphocyte-associated antigen 4. J Exp Med 2000, 192:303-310.

29. Seddon B, Mason D: Regulatory $\mathbf{T}$ cells in the control of autoimmunity: the essential role of transforming growth factor $b$ and interleukin 4 in the prevention of autoimmune thryroiditis in rats by peripheral CD4+ CD45RC- cells and CD4+ CD8- thymocytes. J Exp Med 1999, 89:279-288.

30. Powrie F, Carlino J, Leach MW, Mauze S, Coffman RL: A critical role for transforming growth factor-beta but not interleukin 4 in the suppression of $T$ helper type I-mediated colitis by CD45RB(low) CD4+ T cells. J Exp Med 1996, I 83:2669-2674.

31. Nakamura K, Kitani A, Strober W: Cell contact-dependent immunosuppression by CD4(+)CD25(+) regulatory $T$ cells is mediated by cell surface-bound transforming growth factor beta. J Exp Med 200I, I 94:629-644.

32. Green EA, Gorelik L, McGregor CM, Tran EH, Flavell RA: CD4+CD25+ $T$ regulatory cells control anti-islet CD8+ $T$ cells through TGF-beta-TGF-beta receptor interactions in type I diabetes. Proc Natl Acad Sci USA 2003, I 00:10878-10883.

33. Oida $T$, Zhang $X$, Goto $M$, Hachimura S, Totsuka M, Kaminogawa $S$, Weiner HL: CD4+CD25- $T$ cells that express latency-associated peptide on the surface suppress CD4+CD45RBhighinduced colitis by a TGF-beta-dependent mechanism. J Immunol 2003, I70:2516-2522.

34. Sundstedt A, O'Neill EJ, Nicolson KS, Wraith DC: Role for IL-I 0 in suppression mediated by peptide-induced regulatory $T$ cells in vivo. J Immunol 2003, I 70: I 240- I 248

35. Groux H, O'Garra A, Bigler M, Rouleau M, Antonenko S, de Vries JE, Roncarolo MG: A CD4+ T-cell subset inhibits antigen-specific T-cell responses and prevents colitis. Nature 1997, 389:737-742.

36. Roncarolo MG, Bacchetta R, Bordignon C, Narula S, Levings MK: Type I T regulatory cells. Immunol Rev 200I, I 82:68-79.

37. Buer J, Lanoue A, Franzke A, Garcia C, von Boehmer H, Sarukhan A: Interleukin 10 secretion and impaired effector function of major histocompatibility complex class II-restricted T cells anergized in vivo. J Exp Med 1998, 187:177-183. 
38. Barrat FJ, Cua DJ, Boonstra A, Richards DF, Crain C, Savelkoul HF, de Waal-Malefyt R, Coffman RL, Hawrylowicz CM, O'Garra A: In vitro generation of interleukin 10 -producing regulatory CD4(+) $T$ cells is induced by immunosuppressive drugs and inhibited by $T$ helper type I (ThI)- and Th2-inducing cytokines. J Exp Med 2002, 195:603-6I6.

39. Pontoux C, Banz A, Papiernik M: Natural CD4 CD25(+) regulatory $T$ cells control the burst of superantigen-induced cytokine production: the role of IL-I0. Int Immunol 2002, 14:233-239.

40. Vieira PL, Christensen JR, Minaee S, O'Neill EJ, Barrat FJ, Boonstra A, Barthlott T, Stockinger B, Wraith DC, O'Garra A: IL-10 secreting regulatory $T$ cells do not express Foxp 3 but have comparable regulatory function to naturally occuring CD4+CD25+ regulatory T cells. J Immunol 2004, I 72:5986-5993.

41. Weiner HL: Oral tolerance: immune mechanisms and treatment of autoimmune diseases. Immunol Today 1997, I 8:335-343.

42. Aandahl EM, Michaelsson J, Moretto WJ, Hecht FM, Nixon DF: Human CD4+ CD25+ regulatory $T$ cells control T-cell responses to human immunodeficiency virus and cytomegalovirus antigens. J Virol 2004, 78:2454-2459.

43. Boussiotis VA, Tsai EY, Yunis EJ, Thim S, Delgado JC, Dascher CC, Berezovskaya A, Rousset D, Reynes JM, Goldfeld AE: IL-I 0-producing $T$ cells suppress immune responses in anergic tuberculosis patients. J Clin Invest 2000, 105:1317-1325.

44. Kinter AL, Hennessey M, Bell A, Kern S, Lin Y, Daucher M, Planta M, McGlaughlin M, Jackson R, Ziegler SF, Fauci AS: CD25+CD4+ regulatory $T$ cells from the peripheral blood of asymptomatic HIV-infected individuals regulate CD4 and CD8 HIV-specific $T$ cell immune responses in vitro and are associated with favorable clinical markers of disease status. J Exp Med 2004, 200:331-343.

45. Oswald-Richter K, Grill SM, Shariat N, Leelawong M, Sundrud MS, Haas DW, Unutmaz D: HIV infection of naturally occurring and genetically reprogrammed human regulatory T-cells. PLOS Biol 2004, 2:El 98.

46. Xu D, Liu H, Komai-Koma M, Campbell C, McSharry C, Alexander J, Liew FY: CD4+CD25+ regulatory T cells suppress differentiation and functions of ThI and Th2 cells, Leishmania major infection, and colitis in mice. J Immunol 2003, I70:394-399.

47. Sher A, Coffman RL: Regulation of immunity to parasites by $\mathbf{T}$ cells and T cell-derived cytokines. Annu Rev Immunol 1992, 10:385-409.

48. O'Garra A, Robinson D: Development and function of $\mathrm{T}$ helper I cells. Adv Immunol 2004, 83: 133-162.

49. O'Garra A: Cytokines induce the development of functionally heterogeneous T helper cell subsets. Immunity 1998, 8:275-283.

50. Moore KW, de Waal Malefyt R, Coffman RL, O'Garra A: Interleukin- 10 and the interleukin- 10 receptor. Annu Rev Immunol 200I, 19:683-765.

\section{Publish with Bio Med Central and every scientist can read your work free of charge}

"BioMed Central will be the most significant development for disseminating the results of biomedical research in our lifetime. "

Sir Paul Nurse, Cancer Research UK

Your research papers will be:

- available free of charge to the entire biomedical community

- peer reviewed and published immediately upon acceptance

- cited in PubMed and archived on PubMed Central

- yours - you keep the copyright

Submit your manuscript here:

http://www.biomedcentral.com/info/publishing_adv.asp
BioMedcentral 